\section{Research Article}

(c) 2021 Michal Beno.

This is an open access article licensed under the Creative Commons Attribution-NonCommercial 4.o International License

(https://creativecommons.org/licenses/by-nc/4.o/)

\title{
Face-to-Display Working: Decarbonisation Potential of not Commuting to Work before Covid-19 and during and after Lockdowns
}

\author{
Michal Beno \\ Institute of Technology and Business in Ceske Budejovice, \\ 370 o1 Ceske Budejovice, Czech Republic
}

DOI: https://doi.org/10.36941/ajis-2021-oo6o

\begin{abstract}
The main goal of this study was to examine whether full face-to-display working instead of commuting to work is a suitable solution for carbon emission reduction. Data from an international Austrian company were used. The study adopted cross tabulation for analysing the relationships of commuting (carbon emissions) in different periods in relation to face-to-display environmental benefits. The study analysed whether the major benefit of e-working, namely not commuting to work, can reduce carbon emissions. Real evidence of decarbonisation data from an Austrian company was provided. There are significant differences in the numbers of workers in cubicles and at home during the periods. The study reveals that face-to-display work can save $\mathrm{CO}_{2}$ emissions by reducing work-related trips. The data obtained offer a stimulating view of potential carbon emissions savings if employees continue working from home. Additionally, further saving factors correlate with the findings of this study, in particular decreases in energy consumption. Based on the data received, after the easing of the lockdown period, full e-workers mitigated the extent of their carbon footprint by almost $62 \%$ because of transport emissions. Moreover, in that period, $126072 \mathrm{~kg}$ of $\mathrm{CO}_{2}$ emission of energy consumption was saved. Generally, the results indicate that an increase of e-workers tends to decrease the footprint from transport emissions and energy consumption. This paper finds that workers working remotely decrease the carbon foot print as a result of zero commuting and energy consumption during different periods of the Covid-19 pandemic. The findings show that more long-term and comprehensive studies are needed, especially in relation to e-workers who have invested in lower-emission home offices. This study has contributed to highlighting the environmental benefit of reducing $\mathrm{CO}_{2}$ emissions offace-to-display workers by not commuting to work. The findings are based on data from an international Austrian company.
\end{abstract}

Keywords: face-to-display working, commuting, energy consumption, Covid-19

\section{Introduction}

Face-to-display working (teleworking, telecommuting), in brief, working from home, is not a new concept. In the EU, telework increased slowly in the past 10 years with notable disparities in its implementation (Eurostat, 2020). These disparities can be caused by different factors, such as GDP (Brussevich et al., 2020; Gottlieb et al., 2020; López-Calva, 2020), level of the economy (Hatayama et al., 2020), education (Nicholas, 2009), technology (Grant et al., 2013), culture (Pöysäri, 2020) and policies (Weber et al., 2020).

Covid-19 has led to changes in workplace practices, e.g. the wearing of masks, social distancing, 
sanitising and working outside the organisation's premises. A recent study emphasises that the majority of US employees want remote work arrangement to remain (GetAbstract, 2020). Generally, an important benefit of working remotely appears to be a decline in carbon emissions. In $2010,14 \%$ of global greenhouse gas emissions came from the transportation sector (EPA, 2020). On average, European workers spend one hour and 24 minutes a day commuting, travelling $28.56 \mathrm{~km}$ in total (SDWorx, 2018). In Austria, 6.90 million motor vehicles were registered and passenger cars rose to 4.98 million at the end of 2018 (Statistics Austria, 2019). Data show that in 2019 there were about 35736 road accidents in which 45140 people were injured and 416 killed (Statistics Austria, 2020).

Masayuki (2018) presents empirical evidence on the relationship between commuting time and telecommuting in Japan. This paper analysed whether e-working's major benefit, namely not commuting to work, can reduce carbon emissions by providing real evidence of decarbonisation data from an Austrian company. The first research question in this study was to analyse whether face-todisplay work, especially working from home, can limit carbon emissions by reducing work-related journeys in different periods. The second research question was whether face-to-display work contributes to reducing energy consumption, especially from not commuting to work.

The next section presents a literature review consisting of a selection of literature and definitions of the concept relevant to the subject. In the second part, the methodology is introduced. Then follows a section presenting the results of the study. The fourth section is the discussions, and the last part concludes with a summary.

\section{Face-to-Display Working and Commuting}

Telecommuting, virtual office and telework are a few of the terms used to describe the same phenomenon (Siha \& Monroe, 2006). Face-to-display workers are those workers who, in the time of Covid-19, are working outside the organisation's premises using modern technology.

Working from home has various benefits. In this study, commuting has been examined as one of the many advantages. According to Nilles (1997), the accelerator of telecommuting was saving the cost of commuting to work. Ford \& Butts (1991) claim that eliminating the stresses of driving in rush hour may represent the most important advantage for many employees. The benefit of avoiding commuting has been confirmed by different studies (Tremblay \& Thomsin, 2012; Beňo, 2018). Walls et al. (2007) found that several factors related to the commute trip, and that work location influenced telecommuting choice and frequency. Many studies emphasise that commuting to and from work causes physical and mental problems (Novaco \& Gonzalez, 2009; Nomoto et al., 2015), and Long et al. (2013) highlight that implementing telework strategies can result in reduced stress levels.

Kitou \& Horvath (2003) found that in US states with a high telework potential (California, Georgia, Illinois, New York, Texas), telework could reduce emissions, but it would depend on commuting and climatic patterns and the electricity mix. The authors add that environmentally beneficial telework programmes are found to depend mainly on commuting patterns, induced energy usage, and characteristics of the office and home space and equipment use. In the study of Lila \& Anjaneyulu (2017), it was found that telework reduced the distance travelled by $3.2 \%$ and the amount of time spent in traffic by $6.10 \%$. A study from 2014 shows that by working from home for two days a week for a year, an average UK employee can save $390 \mathrm{~kg} \mathrm{CO}_{2} \mathrm{e}, 50$ hours commuting time and $£ 450$ including travel costs (Carbon Trust, 2014).

\section{Methodology}

Firstly, the existing literature on the $\mathrm{CO}_{2}$ savings potential of face-to-display work is discussed. Secondly, a cross tabulation of the data was made. Research was performed by means of a quantitative approach with a target group sample of 120 individuals (employees in Austria) whose employer offers them the option of working from home (see Table 1 ). 
Table 1. Socio-demographic characteristics, $\mathrm{N}=120$.

\begin{tabular}{llc}
\hline Variable & & $\begin{array}{c}\text { Cubicles } \\
\text { N=120 }\end{array}$ \\
\hline \multirow{2}{*}{ Sex } & Male & 68 \\
& Female & 52 \\
\hline \multirow{2}{*}{ Age } & $20-29$ & 28 \\
& $30-44$ & 38 \\
\multirow{2}{*}{ Marital status } & $45-59$ & 37 \\
\hline \multirow{2}{*}{ Parenthood } & Single (divorced, separated) & 67 \\
& Married/partnership & 53 \\
\hline
\end{tabular}

This work was developed to provide a better understanding of employees' commuting in an Austrian company before Covid-19 (29 February 2020), during the first lockdown (31 March 2020), after the easing of the lockdown (31 May 2020) and during the second lockdown (30 November 2020). In the first stage of our survey, we identified cubicle workers and e-workers. Secondly, we examined the commuting trend and energy consumption when they were not commuting. As this data collection was done solely for this international company, ethics approval was not required.

In the first stage, we used cross tabulation of data to examine relationships within the data. In the second stage of our analysis, we used adjusted formulas (World Resources Institute \& World Business Council for Sustainable Development, 2013) to calculate total emissions as a result of commuting for the reporting periods, as follows:

$\sum$ The total distance travelled by rail/car/bike/foot $=\sum$ (daily one-way distance between home and work ( $\mathrm{km})$ ) $x_{2} \times 5 \times$ number of commuting weeks) (1)

and

$\sum$ The emissions from employees commuting for the reporting month $=\sum$ (total distance travelled) $x$ specific emission factor $\mathrm{kg} \mathrm{CO}_{2} e(2)$

Emission factor $\mathrm{kg} \mathrm{CO} e$ - rail (o.1), car (o.2), foot (o) and bike (o.o1).

In the next step, energy consumption was calculated (see Table 2 ).

Table 2. Gross domestic product calculated by the expenditure approach.

\begin{tabular}{cc}
\hline Working environment & Monthly carbon $\left(\mathbf{k g C O}_{2}\right.$ monthly) \\
\hline Home office & 3.34 (Umweltbundesamt, 2019) \\
Offices & 100.20 (Umweltbundesamt, 2019) \\
\hline
\end{tabular}

Source: Author's own elaboration

\section{Results}

\subsection{Workplace formation}

With e-workers as the dependent variable, the outcomes were more straightforward. Table 3 shows a sudden increase in face-to-display workers from before Covid-19 until the second lockdown. The number of remote workers more than doubled the initial figure. This also confirms recent data that the Covid-19 crisis led to companies implementing teleworking on a massive scale (Belzenegui-Eraso \& Erro-Garcés, 2020). 
Table 3. Profiling main place of work during four periods.

\begin{tabular}{lcccc}
\hline Place of work & Before Covid-19 & 1st lockdown & Easing of restrictions & 2nd lockdown \\
\hline Cubicles (N/\%) & $120 / 100$ & $12 / 10$ & $66 / 55$ & $50 / 41.66$ \\
E-workers (N/\%) & $0 / 0$ & $108 / 90$ & $54 / 45$ & $70 / 58.33$ \\
\hline
\end{tabular}

Source: Author's own elaboration

\subsection{Commuting and $\mathrm{CO}_{2} e$}

As indicated in the first section, a study from 2014 shows that by working from home for two days a week for a year, an average UK employee can save $390 \mathrm{~kg} \mathrm{CO}_{2}$ e. The real-evidence approach taken in this study is an attempt to provide real data of decarbonisation from an Austrian company in different Covid-19 time periods.

Loosely speaking, the data shown in Table 4 mean that, if the number of commuters decreases, the total distance travelled by each commute group and the frequency of commuting per week also decreases. In February, a total of $56040 \mathrm{~km}$ was travelled by 120 commuters in the different commute groups, compared to total distance of $61130 \mathrm{~km}$ during the first lockdown, after the easing and during the second lockdown. The average one-way commute distance per commute group was calculated and determined from received data of the respondents as follows: a) rail: $10 \mathrm{~km}$; b) car: $15 \mathrm{~km}$; ) foot: $2 \mathrm{~km}$, and d) bike: $5 \mathrm{~km}$.

Table 4. Commuting data.

\begin{tabular}{lcccc}
\hline Commute group & Before Covid-19 & 1st lockdown & Easing of restrictions & 2nd lockdown \\
\hline Rail $(\mathrm{N}) /($ total distance travelled) & $27 / 10800$ & $\mathrm{o} / 0$ & $12 / 6000$ & $8 / 3200$ \\
Car $(\mathrm{N}) /($ total distance travelled) & $72 / 43200$ & $9 / 2700$ & $36 / 27000$ & $30 / 18000$ \\
Foot $(\mathrm{N}) /($ total distance travelled $)$ & $18 / 1440$ & $3 / 120$ & $13 / 1300$ & $7 / 560$ \\
Bike $(\mathrm{N}) /($ total distance travelled) & $3 / 600$ & $\mathrm{o} / \mathrm{o}$ & $5 / 1250$ & $5 / 1000$ \\
\hline Commuting frequency per week & 5 & 2 & 5 & 4 \\
\hline
\end{tabular}

Source: Author's own elaboration

Using these bases for further calculation of carbon emissions, the results from all the periods after prior-Covid-19 (9726 kg of $\mathrm{CO}_{2} \mathrm{e}$ ) appear to be low: a) first lockdown ( $540 \mathrm{~kg} \mathrm{CO}_{2} \mathrm{e}$ ); b) easing of

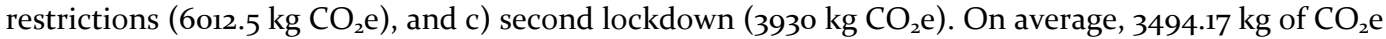
were produced by commuting to work in those three periods. Obviously, the data of the first period in March are even more extreme due to the restrictions of the hard lockdown. Furthermore, full e-workers mitigated the extent of their carbon footprint by almost $62 \%$ as a result of transport emissions after the easing of the lockdown period and by almost $41 \%$ during the second lockdown.

\subsection{Energy consumption}

It might have been expected that the positive effects of e-commuting would partly boost the positive effects of organisations' energy consumption. Instead, there is a slight decline, but there is a noticeable reduction of energy consumption in home offices, as shown in Table 5. In point of fact, the estimated savings are significant, namely $288215 \mathrm{~kg} \mathrm{CO} 2 \mathrm{e}$ during the first lockdown, 126 o72 $\mathrm{kg} \mathrm{CO}_{2} \mathrm{e}$ after the easing and $179358 \mathrm{~kg} \mathrm{CO}{ }_{2} \mathrm{e}$ during the second lockdown. 
Table 5. Energy consumption savings in $\mathrm{kg} \mathrm{CO}_{2} \mathrm{e}$.

\begin{tabular}{lcccc}
\hline Energy & Before Covid-19 & 1st lockdown & Easing of restrictions & 2nd lockdown \\
\hline Home office & 0 & 11182 & 5591 & 7014 \\
Offices & 336672 & 37274 & 205009 & 150300 \\
\hline
\end{tabular}

Source: Author's own elaboration

\section{Discussion}

Face-to-display work can help to reduce the organisation's carbon footprint, as shown in this study. Verbeke et al.'s (2008) data confirm that implementing telework and reducing employees' commute reduces an organisation's carbon footprint. But, the extent of the emission reduction that can be gained from remote work in any particular city depends on a number of factors, from whether most commuters drive cars or take public transit to what electricity sources the city uses (Cruickshank, 2020). Considering this data, should organisations implement more face-to-display work options in the post-pandemic society in relation to environmental benefits? According to Crow \& Millot (2020), working from home can save energy and reduce emissions. The authors' further stress that for people who commute by car $(>6 \mathrm{~km})$ working from home is likely to reduce their carbon dioxide footprint. However, for short car commutes or those done by public transport, working from home could increase $\mathrm{CO}_{2}$ emissions due to extra residential energy consumption (Crow \& Millot, 2020). A recent study shows that for some categories, such as teleworkers and home-based workers, trade-off effects are observed between work and non-work trips, which increase $\mathrm{CO}_{2}$ emission levels (Cerqueira et al., 2020). Everything depends on individual demands relating to commuting. Additionally, different regions of the world derive energy from different sources, so some are more sustainable than others (Turits, 2020).

\section{Conclusion}

This study estimates the impact of face-to-display workers on personal commuting through the cross tabulation analysis of data from an international Austrian company. Four dependent variables were used: workplace formation, commuting, $\mathrm{kg} \mathrm{CO}_{2} \mathrm{e}$ and energy consumption. The study was conducted in three stages. The first stage investigated the workplace formation. In the second stage, commuting and the carbon footprint were analysed. In the last stage, energy consumption was examined.

The main research questions investigated in this paper are:

RQ1: Can face-to-display work save carbon emissions by reducing work-related journeys in different periods? The results from all the periods after pre-Covid-19 (9726 kg of $\left.\mathrm{CO}_{2} \mathrm{e}\right)$ appear to be low: a) first lockdown (540 kg CO$\left.{ }_{2} \mathrm{e}\right)$; b) easing of restrictions $\left(6012.5 \mathrm{~kg} \mathrm{CO}_{2} \mathrm{e}\right.$ ), and c) second lockdown (3930 $\mathrm{kg}$ $\mathrm{CO}_{2} \mathrm{e}$ ). On average $3494.17 \mathrm{~kg} \mathrm{CO} \mathrm{CO}_{2} \mathrm{e}$ were produced by commuting to work in those three periods. Furthermore, full e-workers mitigated the extent of their carbon footprint by almost $62 \%$ as a result of transport emissions after the easing of the lockdown period and by almost $41 \%$ during the second lockdown. In 2008, Sun Microsystem found that the daily commute accounts for more than $98 \%$ of an employee's work-related carbon footprint (Green Car Congress, 2008). According to a recent report, $80 \%$ of remote workers use their home as their primary place of work (Buffer, 2020). Green (2011) points out several eco-friendly advantages resulting from replacing the daily office commute with a working day in the home.

RQ2: Does face-to-display work contribute to saving energy consumption, especially from not commuting to work? There is a slight decline, but there is a noticeable reduction of energy consumption in home offices: namely $288215 \mathrm{~kg} \mathrm{CO}_{2} \mathrm{e}$ during first lockdown, $126072 \mathrm{~kg} \mathrm{CO}_{2} \mathrm{e}$ after the easing and $179358 \mathrm{~kg} \mathrm{CO} \mathrm{CO}_{2} \mathrm{e}$ during second lockdown. But Shimoda et al.'s (2007) results indicate that telecommuting tends to increase energy consumption in the residential sector and to decrease it in the 
non-residential sector. He also notes that energy consumption can increase if the floor area of office buildings is not decreased by sharing the space among telecommuters.

Managing the economy through the greening of the workplace, such as by face-to-display, will continue to increase, as is shown by many international organisations, e. g. Dell (Pfluger et al., 2016), Xerox (Xerox, 2020), Aetna (Aetna Corporate Responsibility, 2011).

An aspect not covered by this research is the analysis of commuting time instead of distance. Zhu (2012) investigated both variables. This issue could be dealt with in future research. Another issue to note is that the results of this study do not necessarily reflect how the ways that workers get to work will evolve in the post-pandemic period.

\section{References}

Aetna Corporate Responsibility (2011). Embracing our responsibility for sustainable heath care. Retrieved from: http://www.aetna.com/about-aetna-insurance/document-library/cr/CorpResp2o11.pdf

Belzunegui-Eraso, A., \& Erro-Garcés, A. (2020). Teleworking in the Context of the Covid-19 Crisis. Sustainability, 12(9), pp. 18. https://doi.org/10.339o/su12093662

Beňo, M. (2018). Working in the Virtual World - an approach to the Home Office Business Model Analysis. Ad Alta: Journal of Interdisciplinary Research, 8(1), pp. 25-36.

Brussevich, M., Dabla-Norris, E., \& Khalid, S. (2020). Who will Bear the Brunt of Lockdown Policies? Evidence from Tele-workability Measures Across Countries. Retrieved from: https://www.imf.org/en/Publications/WP /Issues/2020/06/12/Who-will-Bear-the-Brunt-of-Lockdown-Policies-Evidence-from-Tele-workabilityMeasures-Across-49479.

Buffer (2020). The 2020 State of Remote Work. Retrieved from: https://lp.buffer.com/state-of-remote-work-2020

Carbon Trust (2014). Homeworking: helping business cut costs and reduce their carbon footprint. Retrieved from: https://prod-drupal-files.storage.googleapis.com/documents/resource/public/Homeworking\%2o-

\%2oHelping\%2obusinesses\%2ocut\%2ocosts\%2oand\%2oreduce\%2otheir\%2ocarbon\%2ofootprint\%20\%20REPORT.pdf

Cerqueira, E. D. V., Motte-Baumwol, B., Chevallier, L. B., \& Bonin, O. (2020). Does working from home reduce $\mathrm{CO}_{2}$ emissions? An analysis of travel patterns as dictated by workplaces. Transportation Research Part D: Transport and Environment, 83, pp. 12. https://doi.org/10.1016/j.trd.2020.102338

Crow, D., \& Millot, A. (2020). Working from home can save energy and reduce emissions. But how much? Retrieved from: https://www.iea.org/commentaries/working-from-home-can-save-energy-and-reduce-emissions-buthow-much

Cruickshank, A. (2020). COVID Pandemic-19 Shows Telecommuting Can Help Fight Climate Change. Retrieved from: https://www.scientificamerican.com/article/covid-19-pandemic-shows-telecommuting-can-help-fightclimate-change/

EPA (2020). Global Greenhouse Gas Emissions Data. Retrieved from: https://www.epa.gov/ghgemissions/globalgreenhouse-gas-emissions-data.

Eurofound (2020). COVID-19: Policy responses across Europe. Labour market change. Publications Office of the European Union. Luxembourg.

Eurostat (2020). Employed persons working from home as a percentage of the total employment, by sex, age and professional status (\%). Retrieved from: https://ec.europa.eu/eurostat/databrowser/view/lfsa_ehomp/default/table?lang=en.

Ford, R. C., Butts, M. A. (1991). Is Your Organization Ready for Telecommuting? SAM Advanced Management Journal, 56(4), pp. 19.

GetAbstract (2020). National Survey. Retrieved from: https://journal.getabstract.com/wpcontent/uploads/2020/o4/ga_remote_survey_2020_compressed.pdf.

Gottlieb, Ch., Grobovsek, J., Poschke M., Saltiel, F. (2020). Lockdown Accounting. Retrieved from: http://ftp.iza.org/dp13397.pdf.

Grant, C. A., Wallace, L. M., \& Spurgeon, P. C. (2013). An exploration of the psychological factors affecting remote e-worker's job effectiveness, well-being and work-life balance. Employee Relations, 35(5), 527-546. http://dx.doi.org/10.1108/ER-o8-2012-0059

Green Car Congress. (2008). Sun Microsystems Study Finds Open Work Program Reduces Energy Consumption, Saves Time and Money. Retrieved from: https://www.greencarcongress.com/2008/o6/sun-microsystem.html

Green, P. (2011). Remotely Green: Why Working from Home is the Ultimate Green Move. Retrieved from: https://www.triplepundit.com/story/2011/remotely-green-why-working-home-ultimate-green-move/77221 
Hatayama, M., Viollaz, M., \& Winkler, H. (2020). Jobs' Amenability to Working from Home, Evidence from Skills Surveys for 53 Countries. Policy Research Working Paper 9241. Retrieved from: http://documents1.worldbank.org/curated/en/673341589224762491/pdf/Jobs-39-Amenability-to-Workingfrom-Home-Evidence-from-Skills-Surveys-for-53-Countries.pdf.

Kitou, E., \& Horvath, A. (2003). Energy-Related Emissions from Telework. Environmental Science E Technology, 37(16), pp. 3467-3475. https://doi.org/10.1021/eso25849p.

Lila, P. C., \& Anjaneyulu, M. V. (2017). Networkwide Impact of Telework in Urban Areas: Case Study of Bangalore, India. Journal of Transport and Engineering, Part A: Systems, 143(8). https://doi.org/10.1061/JTEPBS.ooooo61.

Long, Z., Kuang, K., \& Buzzanell, P. M. (2013). Legitimizing and Elevating Telework: Chinese Constructions of a Nonstandard Work Arrangement. Journal of Business and Technical Communication, 27(3), pp. $243-262$. https://doi.org/10.1177/1050651913479912.

López-Calva, L. F. (2020). Working in Times of Pandemic: Only one in five workers in LAC can actually work from home. Retrieved from: https://www.latinamerica.undp.org/content/rblac/en/home/presscenter/director-sgraph-for-thought/working-at-a-distance--the-availability-of-teleworkable--jobs-ano.html.

Masayuki, M. (2018). Long commuting Time and the Benefits of Telecommuting. Retrieved from: https://www.rieti.go.jp/jp/publications/dp/18eo25.pdf.

Nicholas, A. (2009). Millennial Interest in Teleworking: A survey of generational attitudes. VDM Verlag Dr. Müller, $208 \mathrm{p}$.

Nilles, J. M. (1997). Telework: Enabling Distributed Organizations. Information Systems Management, 14(4), pp. 714. https://doi.org/10.108o/10580539708907069.

Nomoto, M., Hara, A., \& Kikuchi, K. (2015). Effects of long-time commuting and long-hour working on lifestyle and mental health among school teachers in Tokyo, Japan. Journal of Human Ergology, 44 (1), pp. 1-9. https://doi.org/10.11183/jhe.44.1_1.

Novaco, R. W., \& Gonzalez, O. I. (20o9). Commuting and well-being. In Y.-Amichai-Hamburger (ed.), Technology and Well-being, December, pp. 174-205. Cambridge University Press.

Pfluger, J., Gibson, S., \& Normand Ch. (2016). The Sustainability Benefits of the Connected Workplace. Retrieved from: https://i.dell.com/sites/csdocuments/Corporate_corp-Comm_Documents/en/telecommute-study.pdf

Pöysäri, A. (2020). Cultural Aspects of telecommuting. Does individualism affect telecommuting outcomes? Retrieved from: https://aaltodoc.aalto.fi/bitstream/handle/123456789/44099/bachelor_P\%C3\%B6ys\%C3\%A4ri_Aleksi_2020.pdf?se quence $=1$ \&isAllowed $=\mathrm{y}$.

SDWorx (2018). More than $20 \%$ of Europeans Commute at Least 90 Minutes Daily. Retrieved from: https://www.sdworx.com/en/press/2018/2018-o9-20-more-than-2opercent-of-europeans-commute-at-least90-minutes-daily.

Shimoda, Y., Yamaguchi, Y., Kawamoto, K., Ueshige, J., Iwai. Y., \& Mizuno, M. (2007). Effect of Telecommuting on energy consumption in residential and non-residential sectors. Retrieved from: https://www.aivc.org/sites/default/files/p653_final_o.pdf

Siha, S. M., \& Monroe, R. W. (2006). Telecommuting's past and future: a literature review and research agenda. Business Process Management Journal, 12(4), pp. 455-482. https://doi.org/10.1108/14637150610678078.

Statistics Austria (2019). Stock of motor vehicles increased in 2018 by $1.8 \%$ to 6.90 million, passenger cars rose to 4.98 million. Retrieved from: https://www.statistik.at/web_en/statistics/EnergyEnvironmentInnovationMobility /transport/road/stock_of_motor_vehicles_and_trailers/120268.html.

Statistics Austria (2020). Road traffic accidents. Retrieved from: http://statistik.at/web_en/statistics /EnergyEnvironmentInnovationMobility/transport/road/road_traffic_accidents/index.html.

Tremblay, D-G., \& Thomsin, L. (2012). Telework and mobile working: analysis of its benefits and drawbacks. International Journal of Work Innovation, 1(1), pp. 100-113. https://doi.org/10.1504/IJWI.2012.047995.

Turits, M. (2020). Why working from home might be less sustainable. Retrieved from: https://www.bbc.com/worklife/article/20200218-why-working-from-home-might-be-less-sustainable

Umweltbundesamt.at (2019). Berechnung von Treibhausgas (THG)-Emissionen verschiedener Energieträger. Retrieved from: https://secure.umweltbundesamt.at/co2mon/co2mon.html.

Verbeke, A., Schulu, R., Greidanus, N., \& Hambley, L. (2008). Growing the Virtual Workplace: The Integrative Value Proposition for Telework. Glos: Edward Elgar Publishing Limited.

Walls, M., Safirova, E., \& Jiang, Y. (2007). What Drives Telecommuting? The Relative Impact of Worker Demographics,Employer Characteristics, and Job Types. Transportation Research Record: Journal of the Transportation Research Board, 2020(1), pp. 111-120. https://doi.org/10.3141/2010-13.

Weber, T. et al. (2020). COVID-19: Policy responses across Europe, Luxembourg: Publications Office of the European Union. 
World Resources Institute \& World Business Council for Sustainable Development (2013). Technical Guidance for

Calculating Scope 3 Emissions (version 1.0). Retrieved from:

https://ghgprotocol.org/sites/default/files/standards/Scope3_Calculation_Guidance_o.pdf.

Xerox (2020). Virtual Office Program. Retrieved from: https://www.xerox.com/en-us/jobs/work-from-home

Zhu, P. (2012). Are telecommuting and personal travel complements or substitutes? The Annals of Regional Science, 48, pp. 619-639. https://doi.org/10.1007/soo168-011-046o-6 